\title{
Pembelajaran Kooperatif Bamboo Dancing untuk Meningkatkan Aktivitas dan Hasil Belajar Fisika Materi Pokok Besaran dan Satuan
}

\author{
Indriani \\ SMP Negeri 1 Praya, Lombok, Indonesia \\ *Coresponding Author: indriani87@gmail.com
}

\begin{abstract}
Abstrak: Salah satu penyebab rendahnya mutu pendidikan adalah sebagian besar metode pembelajaran masih bersifat tradisional. Dimana proses pembelajaran sering didominasi dengn metode ceramah sehingga interaksi antara siswa yangg satu dengn yangg lainnya kurang dan hasil belajarnyapun rendah khususnya pada mata pelajaran IPA Fisika. Dengn menerapkan model pembelajaran koperatif tipe Bamboo Dancing diharapkan mampu meningkatkan aktivitas dan hasil belajar siswa kelas VII materi pokok Besaran dan Satuan SMP Negeri 1 Praya Timur. Hasil penelitiaan ini adalah, pada siklus I rata-rata nilai evaluasi siswa adalah 64,91 dengn persentase ketuntasan $68,75 \%$, sedangkan hasil observasi aktivitas siswa diperoleh skor rata-rata 37,5 ini menunjukkan kategori cukup aktif. Pada siklus II rata-rata nilai evaluasi siswa 73,24 dengn persentase $87,50 \%$ dimana hasil observasi aktivitas siswa diperoleh skor rata-rata 46 ini menunjukkan kategori aktif. Sehingga dapat disimpulkan bahwa penerapan model pembelajaran koperatif tipe Bamboo Dancing dapat meningkatkan aktivitas dan hasil belajar fisika kelas VII pokok bahasan Besaran dan Satuan semester ganjil SMP Negeri 1 Praya Timur tahun pelajaran 2019/2020.
\end{abstract}

Kata Kunci: Pembelajaran Koperatif, Bamboo Dancing, Besaran dan Satuan

\section{PENDAHULUAN}

Tujuan pendidikan adalah seperangkat hasil pendidikan yangg dicapai oleh peserta didik setelah diselenggarakan kegiatan pendidikan yaitu bimbingan pengajaran atau latihan yangg diarahkan untuk mencapai tujuan pendidikan. Dalam konteks isi tujuan merupakan suatu komponen pendidikan yangg menempati kedudukan fungsi sentral (Hamalik, 2001).

Selain pendidikan nasional tersebut sangatlah relevan dengn kondisi dalam era globalisasi saat ini. Dimana suasana kehidupan menjadi semakin rumit, cepat berubah, dan sulit diprediksi. Kondisi ini membawa dampak persaingan yangg sangat ketat untuk mendapatkan kehidupan yangg layak, siapa yangg memiliki keunggulan kompetetif dialah yangg akan mendapatkan kemudahan hidup.

Pendidik di sekolah merupakan pendidikan formal yangg diselenggarakan melalui proses pembelajaran. Proses pembelajaran diharapkan mampu menghasilkan siswa yangg mempunyai kemampuan berpikir logis, kreatif terhadap perubahan dan perkembangan. Tampaknya diperlukan tranformasi paendidikan dalam menghadapi era pembangunan, dari belajar secara mnenghafal ke belajar secara berfikir, dari belajar secara dangkal ke belajar secara mendalam. Proses pendidikan di sekolah merupakan kegiatan belajar yangg pokok, ini berarti bahwa berhasil tidaknya pencapaian tujuan pendidikan banyak bergantung pada bagaimana proses belajar yangg dialami siswa sebagai anak pendidik.

Rendahnya prestasi belajar siswa masih menjadi kendala yangg sangat besar bagi dunia pendidikan. Rendahnya prestasi belajar tersebut dipengaruhi oleh banyak faktor diantaranya faktor intern siswa seperti kesiapan, minat, motivasi, intelegensi, 
sikap terhadap belajar dan faktor eksternalnya seperti model pembelajaran yangg dikembangkan oleh guru (Slameto, 1999).

Masalah pendidikan yangg utama di Indonesia adalah sangat rendahnya mutu pada setiap jenjang pendidikan. Setelah dilakukan perbaikan dalam bidang pendidikan, semakin disadari bahwa semakin banyak kekurangan. Kekurangan tersebut adalah terletak pada inti kegiatan pendidikan itu sendiri yaitu proses belajar mengajar yangg melibatkan anak didik dan pendidik, salah satu contoh yaitu penggunaan suatu metode mengajar. Salah satu metode yangg sering digunakan yaitu metode ceramah. Metode ceramah adalah metode yangg boleh dikatakan metode tradisional, karena sejak dulu metode ini telah dipergunakan sebagai alat komunikasi lisan antara guru dengn siswa. Dalam penerapannya, proses belajar mengajar lebih berpusat pada guru, siswa hanya mendengar, menulis, dan menghapal materi yangg diajarkan.

Informasi yangg diperoleh dari hasil observasi adalah dengn menggunakan metode ceramah, siswa sering mengalami kesulitan dalam memahami materi yangg diajarkan. Selain itu juga, kebanyakan siswa memilih bermain dan tidak mendengarkan penjelasan guru saat belajar di kelas karena bagi mereka sangat membosankan.

Berdasarkan hasil pengamatan awal peneliti di atas, siswa SMP Negeri 1 Praya Timur umumnya belum memiliki interaksi belajar yangg bersifat koperatif artinya belajar secara bersama dalam suatu kelompk, dimana siswa masih belajar secara individu tanpa ada saling tukar pikiran.

Berdasarkan pada latar belakang di atas, di sini peneliti bermaksud melakukan penelitian dengn judul "penerapan model pembelajaran koperatif tipe Bamboo Dancing untuk meningkatkan aktivitas dan hasili belajar siswa materi pokok Besaran dan Satuan kelas VII semester ganjil SMP Negeri 1 Praya Timur Tahun Pelajaran 2019/2020".

\section{KAJIAN TEORI}

\section{Model Pembelajaran Koperatif}

Model pembelajaran adalah suatu perencanaan atau suatu pola yangg digunkan sebagai pedoman dalam merencanakan pembelajaran di kelas atau pembelajaran dalam tutorial dan untuk menentukan perangkat-perangkat pembelajaran termaksud di dalam buku-buku, film, komputer, kurikulum, dan lain-lain. Model pembelajaran koperatif adalah sebuah kelompk strategi pengajaran yangg melibatkan siswa bekerja secara kolaborasi untuk mencapai tujuan bersama. Pembelajaran koperatif muncul dari konsep bahwa siswa akan lebih mudah menemukan dan memahami konsep yangg sulit jika mereka saling berdiskusi dengn temannya (Trianto, 2007). Setiap siswa bertanggung jawab atas belajar mereka sendiri dan berusaha menemukan informasi untuk menjwab pertanyaan-pertanyaanyangg dihadapkan pada mereka (Suprijono, 2009).

Setiap siswa bertanggung jawab atas belajar mereka sendiri dan berusaha menemukan informasi untuk menjawab pertanyaan-pertanyaan yangg dihadapkan kepada mereka. Di dalam kelas koperatif siswa belajarbersama dalam kelompkkelompk kecil yangg terdiri dari 4-6 siswa yangg sederajat tetapi heterogen, kemampuan jenis kelamin, suku/ras, dan satu sama lain saling membantu kelompk (Suprijono, 2009). 
Berdasarkan difinisi diatas maka dapat disimpulkan bahwa model pembelajaran koperatif adalah kerangka konseptual yangg melukiskan prosedur sistematis dalam mengorganisasikan pengalaman belajar untuk mencapai tujuan belajar yangg dilakukan dengn cara berkelompk sehingga bisa memberikan kesempatan kepada peserta didik untuk bekerja sama dengn siswa lainnya

\section{Pembelajaran Koperatif Metode Bamboo Dancing}

Pembelajaran dengn metode Bamboo Dancing Pembelajaran dengn tipe Bamboo Dancing serupa dengn tipe inside-outside circle. Pembelajaran diawali dengn pengenalan topik oleh guru. Guru bisa menuliskan topik tersebut di papan tulis atau dapat pula guru bertanya jawab apa yangg diketahui peserta didik mengenai topik itu. Kegiatan sumbang saran ini dimaksudkan untuk mengaktifkan struktur kognitif yangg telah dimiliki siswa agar lebih siap menghadapi pelajaran yangg lain.

Selanjutnya, guru membagi kelas menjadi 2 kelompk besar. Jika dalam satu kelas ada 40 orang, maka tiap kelompk besar terdiri 20 orang. Aturlah sedemikian rupa pada tiap-tiap kelompk besar yaitu 10 orang berdiri berjajar saling berhadapan dengn 10 orang lainnya yangg juga dalam posisi berdiri berjajar. Dengn demikian di dalam tiap-tiap kelompk besar mereka saling berpasang-pasangan. Pasangan ini disebut sebagai pasangan awal. Bagikan tugas kepada setiap pasangan untuk dikerjakan atau dibahas. Pada kesempatan ini berikan waktu yangg cukup kepada mereka agar mendiskusikan tugas yangg diterimanya.

Usai diskusi, 20 orang dari tiap-tiap kelompk besar yangg berdiri berjajar saling berhadapan itu bergeser mengikuti arah jarum jam. Dengn cara ini tiap-tiap peserta didik akan mendapat pasangan baru dan berbagi informasi, demikian seterusnya. Pergeseran searah jarum jam baru berhenti ketika tiap-tiap peserta didik kembali kepasangan asal.

Hasil diskusi di tiap-tiap kelompk besar kemudian dipresentasikan kepada seluruh kelas. Guru memfasilitasi terjadinya intersubjektif, dialog interaktif, tanya jawab, dan sebagainya. Kegiatan ini dimaksudkan agar pengetahuan yangg diperoleh melalui diskusi di tiap-tiap kelompk besar dapat diobjektivikasi dan menjadi pengetahuan bersama seluruh kelas (Suprijono, 2009).

Metode ini tampaknya sangat bermanfaat guna membangun kebersamaan antar siswa. Dalam metode ini tidak terjadi persaingan, siswa saling berbagi informasi . Diskusi antar siswa terjadi pada saat berpasangan dan pada saat presentasi topik pelajaran. Hal ini sangat bermanfaat guna mengaktifan siswa.

Sayanggnya pada metode ini jika dibentuk kelompk besar guru harus menyiapkan topik yangg banyak. Topik yangg terlalu banyak juga akan berakibat pada saat diskusi karena membutuhkan waktu yangg relatif lama.

\section{METODE PENELITIAN}

Adapun rencana penelitian yangg dirancang adalah berupa tindakan untuk meningkatkan aktivitas dan hasil belajar siswa pada mata pelajaran fisika khususnya pada materi pokok besaran dan satuan dengn pendekatan koperatif tipe Bamboo Dancing pada siswa kelas VII SMPN 1 praya timur Tahun Pelajaran 2019/2020. Menurut Taggart (dalam Zainal Aqib, 2006) prosedur pelaksanaan penelitian tindakan kelas mencakup: 1) Penetapan fokus masalah penelitian; 2) Perencanaan Tindaka; 3) Pelaksanaan Tindakan; 4) Pengamatan Interpretasi; dan 5) Refleksi 
Untuk lebih jelasnya secara singkat langkah-langkah rencana pelaksanaan penelitian tindakan kelas (PTK) dapat ditunjukan dalam bagan berikut (Zaenal Aqib, 2006).

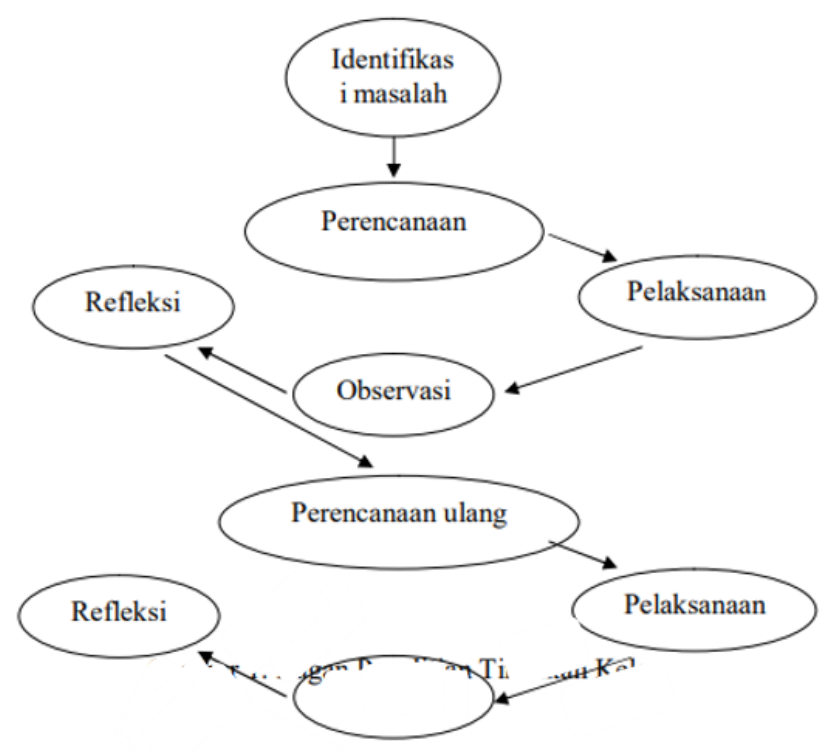

Gambar 1. Suklus pelaksanaan penelitian PTK.

\section{Teknik Pengumpulan Data}

Teknik pengumpulan data dalam penelitian ini adalah sebagai berikut:

a. Sumber Data Sumber data dalam penelitian ini adalah siswa kelas VII Negeri 1 Praya Timur dan guru fisika.

b. Jenis Data

Jenis data dari penelitian ini terdiri dari: 1) Data kuantitatif diperoleh dari hasil evaluasi belajar siswa. 2) Data kualitatif diperoleh dari hasil observasi aktivitas siswa dan guru dalam proses belajar mengajar.

c. Cara Pengambilan Data

Cara pengambilan data dalam penelitian ini adalah: 1) Data hasil belajar diperoleh dengn cara memberikan tes evaluasi atau ulangan pada siswa setiap akhir siklus. 2) Data tentang situasi belajar mengajar diperoleh dari hasil observasi

\section{Instrument Penelitian}

Instrumen yangg akan dilakukan pada penelitian ini adalah sebagai berikut: a) Tes adalah serentetan pertanyaan atau latihan yangg digunakan untuk mengukur keterampilan intelegensi, kemampuan atau bakat yangg dimiliki oleh individu atau kelompk (Suharsimi, 2006). Tes ini akan diberikan setiap berakhirnya siklus untuk memperoleh hasil belajar. Jenis tes yangg digunakan berupa pilihan ganda yangg berjumlah 20 butir soal. b) Lembar Observasi, Observasi disebut juga pengamatan. Jenis observasi yangg akan digunakan pada penelitian ini adalah observsi sistematis dengn menggunakan pedoman sebagai instrumen pengamatan dan berisi sebuah daftar jenis kegiatan guru dan siswa yangg diamati. Dengn kata lain observasi dilengkapi dengn format pengamatan sebagai instrumen dan disusun berisi item-item tentang tingkah laku yangg digambarkan yangg akan terjadi. Dalam proses observasi ini, pengamat akan tinggal memberikan tanda centang atau tanda lainnya pada kolom 
tempat peristwa. Observasi dilakukan pada saat dilaksanakannya tindakan untuk memperoleh data tentang situasi belajar mengajar.

\section{Teknis Analisis Data}

\section{Data aktivitas belajar siswa}

Data aktivitas siswa dianalisis dengn cara berikut: 1. Data tentang aktivitas siswa dianalisis secara deskriptif kualitatif. Indikator tentang aktivitas siswa yangg diamati adalah sebanyak 5 indikator. Skor maksimal setiap indikator adalah 12 dan skor minimal setiap indikator adalah 1. Jadi skor maksimal dan minimal dari seluruh indikator adalah 60 dan 15 .

\section{Data hasil belajar siswa}

Untuk mengetahui hasil belajar siswa, hasil tes belajar siswa dianalisis secara kuantitatif yaitu dengn menentukan rata-rata nilai hasil tes.

\section{HASIL DAN PEMBAHASAN}

Penelitian ini merupakan penelitian tindakan kelas (PTK) dengn menerapkan pembelajaran koperatif tipe Bambo Dancing yangg dilakukan untuk meningkatkan aktivitas dan hasil belajar IPA fisika khususnya pada materi pokok besaran dan satuan siswa kelas VII smester I SMPN 1 praya timur. Penelitian ini dilaksanakan dari tanggal 06 september 2011 sampai dengn 22 september 2011 yangg terdiri dari 2 siklus. Adapun data yangg diperoleh ada dua yaitu data kualitatif dan data kuantitatif. Data kualitatif merupakan data yangg berupa hasil observasi yangg diperoleh selama pelaksanaan tindakan, sedangkan data kuantitatif merupakan data hasil evaluasi pada setiap akhir siklus untuk mengetahui berhasil atau tidaknya proses pembelajaran yangg diukur dengn ketuntasan belajar siswa. Adapun data-data yangg diperoleh dipaparkan sebagai berikut:

\section{Siklus I}

\section{a. Perencanaan}

Hal pokok yangg perlu disiapkan peneliti sebelum melaksanakan tindakan untuk siklus I yaitu : 1) Membuat rencana pelaksanaan pembelajaran; 2) Menyiapkan lembar observasi untuk mencatat aktivitas siswa dan aktivitas guru; 3) Menyiapkan lembar kegiatan siswa; 4) Menyiapkan alat evaluasi; 5) Menyiapkan kunci jawaban alat evaluasi

\section{b. Pelaksanaan Tindakan}

1) Proses pembelajaran metode bamboo dancing

Proses belajar mengajar pada siklus I dilaksanakan dalam tiga kali pertemuan ( tanggal 6,7, dan 11 September 2011), Dimana tiap pertemuan itu berlangsung 2 x 40 menit. Materi yangg dibahas adalah materi besaran dan satuan. Tes hasil belajar dilaksanakan pada tanggal 12 September 2011. Adapun awal kegiatan pembelajaran, guru memperkenalkan model pembelajaran koperatif tipe Bamboo Dancing agar pembelajaran berjalan dengn baik, kemudian guru menyampaikan tujuan pembelajaran, lalu guru menjelaskan pengertian besaran dan satuan, seterusnya guru meminta siswa untuk duduk bersama anggota kelompk yangg telah dibagikan dan membagikan nomor sesuai jumlah anggota kelompknya.

Selanjutnya guru membagikan LKS pada masing-masing kelompk dan memberikan kesempatan kepada siswa untuk berdiskusi dengn anggota kelompknya, 
dalam berdiskusi diharapkan untuk bekerjasama dan saling membantu apabila ada salah satu anggota kelompk yangg belum mengerti. Selama diskusi berlangsung guru memantau kerja tiap-tiap anggota kelompk dan membimbing siswa yangg mengalami kesulitan agar siswa dapat menyimpulkan materi yangg telah dibahas saat diskusi berlangsung terlihat beberapa siswa yangg aktif sedangkan yangg lain tidak terfokus perhatiannya.

Setelah selesai melaksanakan diskusi, guru mengajukan beberapa pertanyaan kepada siswa dan memanggil nomor yangg sama dari tiap-tiap kelompk untuk maju ke depan untuk menjawab soal yangg diajukan dan dari jawaban siswa guru menyimpulkan jawaban yangg paling benar.

\section{c. Hasil Observasi / Evaluasi}

Hasil observasi dari pengamatan guru bidang studi dengn mengisi lembar obsrevasi, dalam proses belajar mengajar. Dari hasil observasi dan pengamatan yangg dilakukan pada siklus I didapatkan bahwa proses pembelajaran belum berjalan sesuai dengn yangg diinginkan karena terdapat kekurangan-kekurangan. Dari hasil observasi kegiatan guru dapat dilihat bahwa kegiatan yangg telah dilaksanakan guru adalah memberikan motivasi dan apersepsi, memberikan pendampingan pada saat kegiatan belajar mengajar. Berdasarkan hasil observasi tersebut kegiatan guru dikategorikan "baik".

Tabel 1. Data aktivitas guru siklus I

\begin{tabular}{|l|l|l|l|}
\hline \multirow{2}{*}{ No } & \multirow{2}{*}{ Pertemuan } & \multicolumn{2}{|c|}{ Siklus I } \\
\cline { 3 - 4 } & \multicolumn{1}{|c|}{ Total skor } & Kategori \\
\hline 1 & Pertemuan I & 16 & Cukup aktif \\
\hline 2 & Pertemuan II & 18 & Cukup aktif \\
\hline
\end{tabular}

Aktivitas siswa dalam pembelajaran dinilai melalui lembar observasi. Adapun ringkasan hasil obsrevasi aktivitas siswa siklus I dapat dilihat pada tabel di bawah ini.

Tabel 2. Data aktivitas siswa siklus I

\begin{tabular}{|c|c|c|c|}
\hline \multirow{2}{*}{ No } & \multirow{2}{*}{ Pertemuan } & \multicolumn{2}{|c|}{ Siklus I } \\
\cline { 3 - 4 } & & Rata-rata & Kategori \\
\hline 1 & Pertemuan I & 37,5 & Cukup aktif \\
\hline 2 & Pertemuan II & 37,5 & Cukup aktif \\
\hline
\end{tabular}

Tabel di atas menunjukan bahwa indikator keberhasilan yangg dicapai siswa pada siklus I masih rendah, sehingga perlu dilanjutkan ke siklus II.

Setelah proses pembelajaran pada siklus I selesai dilaksanakan maka dilakukan evaluasi yangg diberikan dalam bentuk tes obyektif. Selanjutnya hasil analisis evaluasi siklus I dapat terlihat pada table 3.

Tabel 3. Data Hasil Belajar Siswa Pada siklus I

\begin{tabular}{|c|c|c|c|c|c|c|}
\hline Siklus & $\begin{array}{c}\text { Jumlah } \\
\text { siswa }\end{array}$ & $\begin{array}{c}\text { Jumlah } \\
\text { siswa } \\
\text { tuntas }\end{array}$ & $\begin{array}{c}\text { Jumlah } \\
\text { siswa } \\
\text { tidak } \\
\text { tuntas }\end{array}$ & $\begin{array}{c}\text { Nilai } \\
\text { rata- } \\
\text { rata }\end{array}$ & $\begin{array}{c}\text { Persentase } \\
\text { ketuntasan }\end{array}$ & Ket \\
\hline I & 32 & 22 & 10 & 64,91 & 68,75 & $\begin{array}{c}\text { Tidak } \\
\text { tuntas }\end{array}$ \\
\hline
\end{tabular}


Berdasarkan tabel di atas, ketuntasan belajar siswa secara klasikal adalah 68,75 $\%$, hal ini menujukan bahwa ketuntasan klasikal belum mencapai standar klasikal minimal yaitu $85 \%$. Hal ini indikator keberhasilan untuk hasil belajar siswa belum tercapai. Oleh karena itu, perlu dilakukan perbaikan pada siklus berikutnya.

\section{d. Refleksi}

Berdasarkan hasil observasi yangg diperoleh selama pelaksanaan siklus I terdapat kekurangan-kekurangan yangg harus diperbaiki pada siklus berikutnya. Perbaikan-perbaikan yangg harus dilakukan antara lain: 1) Guru harus mampu membangun komunikasi yangg interaktif dengn siswa, baik dalam menyampaikan apresiasimaupun dalam menyampaikan beberapa konsep penting yangg belum dikuasai siswa; 2) Guru harus bisa mengaitkan materi yangg sebelumnya dengn materi yangg sedang diajarkan. Dengn demikian, guru memeiliki bahan diajukan acuan; 3) Guru harus bisa menciptakan suasana persaingan antar kelompk dan memberikan penghargaan pada kelompk yangg bisa menjawabsoal yangg tidak bisa menjawab oleh kelompk lain; 4) Guru harus mengarahkan siswa untuk materi yangg di bahas; dan 5) Meminta keberanian siswa dalam mengemukakan pendapatnya untuk menyimpulkan materi yangg telah selesai dibahas.

\section{Siklus II}

a. Perencanaan

Hal pokok yng perlu disiapkan peneliti sebelum melaksanakan tindakan untuk siklus II yaitu: 1) Membuat rencana pelaksanaan pembelajaran sesuai dengn model pembelajaran bamboo dancing 2) Menyiapkan lembar kegiatan siswa (LKS) untuk melibatkan siswa secara optimaldalam proses pembelajaran 3) Membuat lembar observasi, untuk mengetahui bagaimana aktivitas guru dan aktivitas siswa selama proses pembelajaran berlangsung. 4) Menyusun tes hasil belajar untuk mengetahui hasil belajar siswa; dan 5) Menyiapkan konci jawaban.

b. Pelaksanaan Tindakan

Pada siklus II diusahakan perbaikan-perbaikan terhadap kegiatan pembelajaran sebelumnya berdasarkan hasil observasi dan saran-saran dari guru pendamping. Pembelajaran siklus ini dilaksanakan tiga kali pertemuan. Tindakan pada siklus II sama dengn siklus I. Guru melaksanakan pembelajaran di kelas sesuai dengn rencana yangg telah diterapkan dalam rencana pembelajaran. Pembelajaran dengn tife Bamboo dancing serupa dengn tife inside outside circle. Pembelajaran diawali dengn pengenalan topik oleh guru, selanjutnya membagi kelas menjadi 2 kelompk besar. Jika satu kelas ada 40 orang, maka tiap kelompk besar terdiri 20 orang. Aturlah demikian rupa pada tiap-tiap kelompk besar yaitu 10 orang berarti berjajar saling berhadapan dengn 10 orang lainya yangg juga dalam posisi berdiri berjajar. Dengn demikian di dalam tiap-tiap kelompk besar mereka saling berpasang-pasangan, pasangan ini disebut pasangan awal. Usai diskusi, 20 orang tiap-tiap kelompk besar yangg berdiri berjajar saling berhadapan itu bergeser mengikuti arah jarum jam. Dengn cara ini tiap-tiap peserta didik akan mendapat pasangan baru dan berbagi informasi, demikian seterusnya. Pergeseran searah jarum jam baru berhenti ketika tiap-tiap peserta didik kembali kepasangan awal.

Setelah siswa selesai mendiskusikan LKS, hasil diskusi di tiap-tiap kelompk besar kemudian dipersentasikan kepada seluruh kelas. Guru memfasilitasi terjadinya intersubjektif, dialog interaktif, tanya jawab, dan sebagainya. Kegiatan ini dimaksudkan agar pengetahuan yangg diperoleh melalui diskusi tiap-tiap kelompk 
besar dapat diobjektivikasi dan menjadi pengetahuan bersama seluruh kelas (Suprijono, 2009).

c. Hasil Observasi dan Evaluasi

Berdasarkan hasil observasi yangg dilakukan pada siklus II terlihat adanya peningkatan baik dari aktivitas siswa maupun aktivitas guru. Walaupun masih terlihat kekurangan-kekurangan. Berdasarkan hasil observasi guru pada siklus II ini, dapat dilihat bahwa kegiatan belajar mengajar sudah lebih baik dari siklus I dan semua indikator aktivitas guru telah dilaksanakan, data tetang hasil observasi aktivitas guru pada siklus II.

Tabel 4. Data aktivitas guru siklus II

\begin{tabular}{|c|c|c|c|}
\hline \multirow[b]{2}{*}{ No } & \multirow[b]{2}{*}{ Pertemuan } & \multicolumn{2}{|c|}{ Siklus II } \\
\hline & & Jumlah sekor & Kategori \\
\hline 1 & Pertemuan I & 20 & Cukup \\
\hline 2 & Pertemuan II & 23 & Baik \\
\hline
\end{tabular}

Tabel 4 hasil observasi aktivitas guru diatas terlihat bahwa guru sudah dapat dikatakan berhasil menerapkan moedel pembelajaran Bamboo Dancing dalam kegiatan pembelajaran. Berdasarkan hasil observasi, guru sudah dapat mengendalikan kondisi yangg mengganggu proses belajar mengajar, meskipun terdapat hal-hal yangg perlu ditingkatkan.

Hasil observasi aktivitas siswa dalam pembelajaran pada siklus II terlihat mengalami peningkatan dari siklus sebelumnya. Adapun ringkasannya dapat dilihat pada tabel 5.

Tabel 5. Data aktivitas siswa siklus II

\begin{tabular}{|c|c|c|c|}
\hline \multirow{2}{*}{ No } & \multirow{2}{*}{ Pertemuan } & \multicolumn{2}{|c|}{ Siklus II } \\
\cline { 3 - 4 } & Pertemuan I & Rata-rata & Kategori \\
\hline 2 & Pertemuan II & 46 & Aktif \\
\hline 2
\end{tabular}

Berdasarkan tabel 5 di atas menunjukan bahwa indikator keberhasilan untuk aktivitas belajar siswa pada siklus II telah tercapai setiap pertemuan.

Data tentang hasil evaluasi belajar siswa pada siklus II ini mengalami peningkatan dari siklus I. Adapun ringkasan datanya dapat dilihat pada table 6 .

Tabel 6. Data Hasil Belajar Siswa Pada Siklus II

\begin{tabular}{|l|l|l|l|l|l|l|}
\hline Siklus & $\begin{array}{l}\text { Jumlah } \\
\text { siswa }\end{array}$ & $\begin{array}{l}\text { Jumlah } \\
\text { siswa } \\
\text { tuntas }\end{array}$ & $\begin{array}{l}\text { Jumlah } \\
\text { siswa } \\
\text { tidak } \\
\text { tuntas }\end{array}$ & $\begin{array}{l}\text { Nilai } \\
\text { rata-rata }\end{array}$ & $\begin{array}{l}\text { Persentase } \\
\text { ketuntasan }\end{array}$ & Ket \\
\hline II & 32 & 28 & 4 & 73,24 & 87,50 & Tuntas \\
\hline
\end{tabular}

Hasil tes evaluasi siklus I menunjukan persentase siswa yangg mendapat nilai minimal 65 adalah $68,75 \%$, ini berarti berarti bahwa indikator penelitian belum tercapai dimana tingkat ketuntasan klasikal yaitu 85. Dari data tersebut terdapat 22 siswa yangg memiliki nilai $\geq 65$. Sedangkan hasil evaluasi siklus II menunjukan bahwa persentase ketuntasan siswa yangg mendapat nilai minimal 65 adalah 87,50\%. Dari data tersebut terdapat 28 siswa yangg memiliki nilai $\geq 65$. 


\section{Pembahasan}

Ketuntasan belajar siswa pada siklus I dengn diterapkan pembelajaran koperatif metode Bamboo Dancing belum tercapai sesuai dengn Ketuntasan Klasikal yaitu minimal $85 \%$ siswa nilainya $\geq 65$.

Berdasarkan hasil observasi aktivitas siswa dalam proses pembelajaran masih menunjukkan adanya kekurangan berikut: 1) Siswa kurang berinteraksi dengn kelompknya; 2) Siswa kurang bertanya tentang materi yangg belum dimengerti; 3) Siswa masih kurang berani menjelaskan materi yangg didapatkan sebelumnya pada pasangan berikutnya; 4) Siswa belum mampu memberi tanggapan maupun pendapat pada diskusi kelompk; 5) Siswa belum bisa membuat kesimpulan dari hasil materi yangg dibahas. Sedangkan kekurangan guru pada saat proses pembelajaran adalah kurangnya pemberian konsep-konsep yangg perlu diketahui oleh siswa dan masih kurang memberikan bimbingan pada siswa dalam kegiatan kelompk.

Berdasarkan hasil analisis aktivitas belajar siswa pada siklus I, dimana skor pada pertemuan I sebesar 35 dan pada pertemuan II sebesar 40 sehingga rata-rata aktivitas sebesar 37,5 dan tergolong dalam kategori cukup aktif. Sedangkan hasil dari observasi aktivitas guru pada pertemuan I sebesar 16 dan pertemuan II sebesar 18 sehingga rata-rata aktivitas sebesar 17 dan hasil ini menunjukkan kategori cukup. Untuk itu masih perlu dilakukan perbaikan untuk mengoptimalkan keaktifan siswa dalam proses pembelajaran. Adapun perbaikan yangg perlu dilakukan.

Hasil tes evaluasi menunjukkan dari 32 siswa nilai rata-rata diperoleh 64,91 dengn ketuntasan 68,75 \%. Dari hasil tersebut belum dikatakan tuntas secara klasikal. Untuk itu perlu dilakukan perbaikan pada siklus II seperti yangg dijelaskan di atas.

Setelah dilakukan perbaikan pada siklus II, skor total aktivitas belajar siswa pada pertemuan I sebesar 44 dan pertemuan II sebesar 48 sehingga ratarata aktivitas sebesar 46. Ini menunjukkan bahwa proses belajar siswa sudah tergolong kategori aktif. Sedangkan hasil dari observasi aktivitas guru pada pertemuan I sebesar 20 dan pertemuan II sebesar 23 sehingga rata-rata aktivitas sebesar 21,5 dari hasil ini menunjukkan kategori baik. Akibat dari adanya peningkatan aktivitas siswa maupun guru menyebabkan ketuntasan belajar siswa siklus II pun meningkat menjadi $87,50 \%$, dimana ketuntasan pada siklus I dicapai $68,75 \%$. Sedangkan nilai rata-rata pada siklus II ini meningkat menjadi 73,24 dimana siklus I sebesar 64,91. Dari hasil tersebut menunjukkan ketuntasan belajar siswa dapat dicapai dengn menerapkan model pembelajaran koperatif metode Bamboo Dancing.

Selain itu, penerapan metode Bamboo Dancing (Tari Bambu) seperti hasil penelitian Muhammad Suhardi (Suhardi, 2010) dengn judul "Penerapan Model Pembelajaran Koperatif Metode Bamboo Dancing Untuk Meningkatkan Prestasi Belajar Kimia Pokok Bahasan Larutan Penyanggga Pada Siswa Kelas XI IPA Semester Genap SMA Negeri 1 Praya Timur Tahun Pelajaran 2018/2019” juga mampu meningkatkan prestasi belajar siswa terlihat dari hasil sebagai berikut: pada siklus I skor total aktivitas belajar siswa sebesar 397 dengn rata-rata 11,02 kategori cukup aktif meningkat pada siklus II yaitu skor total aktivitas belajar siswa sebesar 476 dengn rata-rata 12,86 kategori aktif. Dan didapatkan hasil tes evaluasi bahwa nilai rata-rata terjadi peningkatan dari 73,25 menjadi 75,28 dan persentase ketuntasan yangg bisa dicapai pada siklus I hanya $77,77 \%$, sedangkan pada siklus II naik menjadi $88,89 \%$. 
Dari uraian di atas, dapat diketahui bahwa pembelajaran koperatif metode Bamboo Dancing (Tari Bambu) dapat meningkatkan aktivitas dan Hasil belajar siswa, khususnya pada mata pelajaran Fisika pokok bahasan Besaran dan Satuan pada siswa kelas VII Semester ganjil SMP Negeri 1 Praya Timur tahun pelajaran $2019 / 2020$.

\section{KESIMPULAN}

Berdasarkan uraian diatas dapat dasimpulkan: Penerapan model pembelajaran koperatif tipe Bamboo Dancing dapat meningkatkan aktivitas dan Hasil belajar siswa, khususnya pada mata pelajaran matematika pokok bahasan Besaran dan Satuan pada siswa kelas VII-1 semester ganjil SMP Negeri 1 Praya Timur tahun pelajaran 2019/2020.

Adapun saran yangg disampaikan sehubungan dengn hasil penelitian ini adalah a) diharapkan kepada guru untuk dapat menerapkan model pembelajaran koperatif metode Bamboo Dancing sebagai model pembelajaran alternatif dalam kelas, sehingga akan menambah pengalaman bagi guru dalam mengenal variasi pembelajaran dalam upaya meningkatkan aktivitas dan hasil belajar siswa; b) bagi pihak-pihak yangg meneliti lebih lanjut tentang model pembelajaran koperatif metode Bamboo Dancing diharapkan mencoba pada materi yangg lain; c) bagi instansi/sekolah diharapkan memberi dukungan pada guru untuk menerapakan model pembelajaran metode Bamboo Dancing dengn menyediakan media yangg dibutuhkan guna meningkatkan mutu prestasi pembelajaran.

\section{DAFTAR PUSTAKA}

Anonim. (2009). Metode pembelajaran pendidikan. http/www.muhfida.com (22 Desember 2009.

Anonim (2009). Model Pembelajaran Tari Bambu. http/wywld.wordpress.com (22 Desember 2009).

Arikunto, S. (2003). Dasar-dasar evaluasi pendidikan (Edisi revisi). Bumi aksara. Jakrta. Arikunto, S. 2006. Prosedur penelitian suatu pendekatan praktik. Rineka cipta. Jakarta.

Arikunto, Suharsimi. (2010). Penelitian tindakan kelas. Jakarta: Rineka Cipta Aqib, zaenal. 2006. Penelitian tindakan kelas. Rineka Cipta: Jakarta.

Basir. (1988). Evaluasi pendidikan. Airlangga university press. Surabaya

Budiningsih, A. (2005). Belajar dan pembelajaran. Rineka cipta. Jakarta Djali, psikologi pendidikan, (Jakarta: sinar Grafika offset, 2009) (http/goeswarno.blogspot)

Hamalik Oemar. Proses Belajar Mengajar. Jakarta: Rineka Cipta.

Madya, S. (2007). Penelitian tindakan kelas. www.file. Upi. Ed.com (25 agustus 2010)

Mutmainah, M., Dusalan, D., \& Muchlis, M. (2018). PENGARUH PEMBELAJARAN PROBLEM BASED LEARNING TERHADAP KREATIVITAS MATEMATIKA SISWA PADA KELAS VIII UNGGULAN 
MTsN 1 MAKASSAR. SUPERMAT (Jurnal Pendidikan Matematika), 2(2), 1828.

Nana sujana, Dasar-dasaar proses belajar mengajar, (Bandung: Sinar Baru Algensindo, 2010)

Nasir. (1983). Metode penelitian. Ghalia Indonesia. Jakarta.

Slameto. (2003). Belajar dan Faktor-Faktor yangg mempengaruhinya. Rineka cipta. Jakarta Suprijono, A. 2009. Cooperative Learning. Pustaka pelajar. Yogyakarta.

Syarifuddin, S. (2019). IDENTIFIKASI KESULITAN REPRESENTASI MATEMATIS SISWA SMP PADA PEMECAHAN MASALAH PECAHAN. SUPERMAT (Jurnal Pendidikan Matematika), 3(1), 34-42.

Syarifuddin, S. (2018). Pengaruh Pembelajaran Kooperatif Tipe Jigsaw Dan Tipe Group Investigation (GI) Terhadap Ketercapaian Kompetensi Dan Kemampuan Komunikasi Matematika Siswa Di SMA. Jurnal Ilmiah Mandala Education, 4(1), 163-172

Trianto. (2007). Model-model pembelajaran inovatif berorientasi kontruktivisitik. Prestasi Pustaka. Jakarta. Tim Abdi,G. Ipa Terpadu untuk SMP kelas VII.Erlangga. jakarta

Yasa, Doantara. (2008). Aktivitas dan Prestasi Belajar. http/lpotes.wordpress.com (26 November 2009). 